\title{
Molecular phylogeny and synonymy of Balechina gracilis comb. nov. (=Gymnodinium gracile), a widespread polymorphic unarmored dinoflagellate (Dinophyceae)
}

\author{
Gómez Fernando 1, 2, ", Artigas Luis Felipe ${ }^{2}$, Gast Rebecca J. ${ }^{3}$
}

${ }^{1}$ Carmen Campos Panisse 311500 Puerto de Santa María Spain

2 Université du Littoral Côte d'Opale, Université de Lille, CNRS, UMR 8187, LOG, Laboratoire

d'Océanologie et de Géosciences 32 Av. Foch 62930 Wimereux France

3 Woods Hole Oceanographic Institution Woods Hole Massachusetts 02543-1049 USA

* Corresponding author : Fernando Gómez, email address : fernando.gomez@fitoplancton.com

\begin{abstract}
:
Gymnodinium gracile, described from the coasts of Denmark in 1881, is one of the first described unarmored dinoflagellates. Individuals which morphologically fit with the original description were isolated from the English Channel (North-East Atlantic). The SSU rRNA gene sequences were identical to the sequences identified as Balechina pachydermata and Gymnodinium amphora from the Mediterranean Sea and Brazil. We propose the transfer of Gymnodinium gracile into the genus Balechina as B. gracilis comb. nov. These sequences constitute an independent lineage, clustering with numerous environmental sequences from polar to tropical waters. The widespread distribution, the high plasticity in size, shape and coloration and the difficulties in discerning the fine longitudinal striae have contributed to the description of numerous synonyms: Amphidinium vasculum, Balechina pachydermata (=Gymnodinium pachydermatum), Gymnodinium achromaticum, G. abbreviatum, G. amphora, G. dogielii, G. Iohmannii (=G. roseum sensu Lohmann 1908), G. situla and Gyrodinium cuneatum (=G. gracile sensu Pouchet 1885).
\end{abstract}

Keywords : Dinophyta, naked Dinoflagellata, Gymnodiniales, new combination, taxonomy, molecular phylogenetics 
Bergh (1881) described two species of the dinoflagellate genus Gymnodinium from the coasts of Denmark: Gymnodinium gracile and Gymnodinium spirale. The latter is one of the most common and widespread unarmored dinoflagellates currently known as Gyrodinium spirale. Gymnodinium

This article is protected by copyright. All rights reserved 
gracile appears more rarely in the literature (see Appendix S1 in the Supporting Information). Despite the fact that $G$. gracile was described from a region with a long tradition of taxonomic plankton studies, its classification within the current circumscription of Gymnodinium remains unresolved. Briefly, Elbrächter (1979) reported Gymnodinium lohmannii (=Gymnodinium roseum Lohmann nom. illeg.), G. abbreviatum, and Gyrodinium cuneatum (=G. gracile sensu Pouchet 1885 ) as junior synonyms of Gymnodinium gracile (excluding G. gracile sensu Kofoid and Swezy 1921). Hansen and Larsen (1992) illustrated the variability of the shape of G. gracile from individuals collected near the type locality. Gómez et al. (2015) provided SSU rRNA gene sequences for Balechina pachydermata from the Mediterranean Sea and Gymnodinium amphora from Brazil. Based on the SSU rRNA gene phylogeny and morphological variability of the individuals, Gómez et al. (2015) proposed Amphidinium vasculum, Gymnodinium amphora, Gymnodinium dogielii and Gymnodinium gracile sensu Kofoid \& Swezy as synonyms of B. pachydermata. It is unresolved whether Gymnodinium gracile or Gyrodinium cuneatum and Gymnodinium achromaticum, the latter two described from off the coast of Brittany (Pouchet 1885, Lebour 1917) are related to Balechina pachydermata.

This study resolves the synonymy of Gymnodinium gracile with the first LSU rRNA and ITS and the complete SSU rRNA gene sequences of the genus Balechina. Observations were carried out during the research cruise with fifty-one stations sampled from Dunkirk (North Sea) through French coastal and offshore waters of the English Channel, to Brest on July 16-31, 2018 (Fig. S1 in the Supporting Information). Plankton samples were collected from surface waters with a phytoplankton net (20- $\mu \mathrm{m}$ mesh size). Aliquots were left to settle in a composite settling chamber, examined on-board with an inverted microscope (Eclipse TS-100, Nikon Inc., Tokyo, Japan) and photographed with a digital camera (Nikon D5000). Molecular methods are similar to Gómez et al. (2019) and are reported in Appendix S2 in the Supporting Information.

Morphotypes of Gymnodinium gracile were observed in the sampling stations off Normandy and Brittany, with the highest number of cells observed in the French offshore waters between Brest and Plymouth. The species was distinctive, and the only unarmored heterotrophic dinoflagellates within the same range of size were Gyrodinium spirale and Syltodinium listii. Gymnodinium gracile had a premedian cingulum, descending about 3-4 cingular widths, and the cells were wider at the cingulum level. Cell dimensions ranged from 75-140 $\mu \mathrm{m}$ long, and 45-70 $\mu \mathrm{m}$ wide at the cingulum level (Fig. S2 in the Supporting Information), although dividing cells were wider (Fig. S2, 1 and $\mathrm{m}$ ). The main difference between the individuals was the shape of the 
episome. Numerous individuals fit well with the original description of G. gracile showing a pyramidal episome with a blunt apex or a truncated horn (Fig. S2, a-c). The most common morphotype in our samples corresponded to the description of Gymnodinium abbreviatum that is characterized by a lower episome (Fig. S2, d-g). When the apex was contracted, the cell morphology was similar to Gymnodinium amphora or Balechina pachydermata (Fig. S2h). Prior to division, the cell was wider showing the morphology of Gymnodinium situla (Fig. S2h). During oblique cell division (Fig. S2j), the daughter cell with an incomplete episome that received most of the hyposome from the mother cell, initially presented a morphology of Amphidinium vasculum, but later of Gymnodinium pachydermatum, G. amphora or G. achromaticum, the last described from the English Channel at Plymouth (Fig. S2k). The other daughter cell with the complete episome showed a thinner hyposome that corresponded to Gyrodinium cuneatum (=G. gracile sensu Pouchet 1885) that was first described from the coast of Brittany (Fig. S21). Cell shape also influenced other morphological features, such as cingular displacement that is lower in the Gymnodinium amphora morphotype (Fig. S2h) and higher in the Gyrodinium cuneatum morphotype (Fig. S2m). All morphotypes showed the characteristic double-layer thick cell covering. The cell surface lacked prominent ridges or furrows, and it was embossed with fine longitudinal striae difficult to observe with the ship-board optical resources (Fig. S2e). Individuals were hyaline, and colorations (pinky or yellow-greenish) were not observed, except for the vacuoles. Food vacuoles were spherical with a brown color and located in the middle of the cell (Fig. S2, h and $\mathrm{m}$ ). In other cases, the vacuoles were smaller and greenish (Fig. S2m). The nucleus was spherical, encapsulated and located in the hyposome. The presence of a large vacuole may displace the nucleus towards the antapex (Fig. S2h). Individuals of G. gracile swam slowly with gracile movements, but they sometimes experienced sudden accelerations. In contrast to other unarmored dinoflagellates, cells of $G$. gracile did not lyse easily when manipulated and may react with a contraction of the cell body.

We obtained DNA sequences from two samples collected on July 27, 2018 from offshore waters between Brest and Plymouth (4905'28.9" N, 4¹1'24.4" W) and the English Channel waters off Roscoff (4857'17.6" N, 409'28.8" W; Fig. S1). The SSU rDNA sequences (1716, 1712,1359 base pairs) of the three isolates were identical. The percent similarity of Gymnodinium gracile from the English Channel, Balechina pachydermata from the Mediterranean Sea (KR139789) and Gymnodinium amphora from the South Atlantic at Brazil (KR139790-92) 
ranged from 99.5-99.9\%. All these sequences clustered together with full (100\%) bootstrap support as a monophyletic lineage distantly related to any other dinoflagellate sequence (Fig. 1). Gymnodinium gracile is the earliest available name for the members of this lineage, but its generic placement is unsupported because it is distantly related to the Gymnodinium fuscum, type species of Gymnodinium (Fig. 1). In a second tree, we added the closer environmental sequences after a BLAST search. The sequences of Gymnodinium gracile/Balechina pachydermata/Gymnodinium amphora clustered with environmental sequences from southern California (KJ763266, KJ763198, KJ763422), Caribbean Sea (GU825009, GU825612, GU825613, GU825090), Black Sea (HM749926), North Sea (DQ310213, EF526874) and Canadian Arctic (JQ956083; see inset in Fig. 1).

The D1-D2 domains of the LSU rRNA gene sequences of two isolates from distinct locations (off Roscoff, off Finisterre) were identical, and also identical with two undocumented sequences retrieved from GenBank as 'Karenia sp. (in: Dinophyceae) strain DAB07 and DAB08)' isolated from the Black Sea (KU999990-1). These sequences diverged from the sequences of Karenia and its relatives by more than 13\%. The two sequences of Gymnodinium gracile from the English Channel and the isolates from the Black Sea formed a strong supported lineage distantly related to any other dinoflagellate sequence (Fig. S3 in the Supporting Information).

The observations of Gymnodinium gracile showed individuals that fit well with the original description (Fig. S2, a-c), while other individuals were closer to other allied species (Fig. S2, dm). The individuals found in the English Channel off Brittany were hyaline, while it is more common to find individuals with yellow or greenish coloration in warm seas (Kofoid and Swezy 1921, Gómez et al. 2015). The form described as Gymnodinium abbreviatum is the most extended morphotype in the English Channel (Fig. S2m), while in warm waters it is more common to find individuals with the shape of Balechina pachydermata or Gymnodinium amphora (Gómez et al. 2015).

There are numerous taxa described from the morphotypes of Gymnodinium gracile (see Appendix S1). They were described from the observation of one or a few individuals, ignoring the fast changes of shape that characterize the distinct morphotypes of this species (https://www.youtube.com/watch?v=FDytvHEJsFg ). The environmental sequencing data based on the SSU rRNA gene sequences reveals that this species is widely distributed from Arctic waters to tropical waters (Fig. 1). This wide geographical spread and the differences between 
environmental conditions (e.g., polar vs. tropical seas) also contributed to the proliferation of new species descriptions. Another feature is the difficulty of observing the longitudinal striae (Fig.

S2e). The presence or absence of striae was used to propose new species, although this character largely depends on the optical resources. There were anomalies such as the description of Gyrodinium cuneatum with striae in the episome but absent in the hyposome (Kofoid and Swezy 1921).

In the LSU rRNA gene phylogeny, the D1-D2 domains of the two sequences of Gymnodinium gracile from distinct isolates were identical to two undocumented sequences from the Black Sea (KU999990-1) retrieved from GenBank as 'Karenia sp. (in: Dinophyceae) strain DAB07 and DAB08)'. Although the term 'strain' may suggest that the individuals were cultured, the methodology was the direct PCR of isolates. Baytut et al. (2016, p. 55) reported: "we conclude that DAB07 and DAB08 are probably the members of a new genus in the family Kareniaceae", and they did not provide any micrographs. Baytut et al. (2016, their fig. 3) placed the KU9999901 in a phylogenetic tree where the only representative of unarmored dinoflagellates were sequences of the Bachidiniaceae (Karenia, Karlodinium and Takayama). In a phylogenetic tree with a wider representation of unarmored dinoflagellates, there is no support to consider the sequences KU999990-1 belonging to the Brachidiniaceae (Fig. S3). There are records of Gymnodinium gracile (Gómez and Boicenco 2004) and the environmental sequences (HM749926) that support the presence of G. gracile in the Black Sea (Fig. 1).

The molecular data confirm the synonymy of Gymnodinium gracile and B. pachydermata, generitype of Balechina. We propose the transfer of Gymnodinium gracile into Balechina, as B. gracilis.

\section{Balechina gracilis (Bergh) F.Gómez, Artigas \& Gast, comb. nov.}

Basionym: Gymnodinium gracile Bergh (1881, Morph. Jahrb. 7: 251, figs. 68-69).

Heterotypic synonyms: Amphidinium vasculum Kofoid \& Swezy (1921: 156), Balechina pachydermata (Kofoid \& Swezy) Loeblich \& A.R.Loeblich (1968: 210), (=Gymnodinium pachydermatum Kofoid \& Swezy (1921: 239)), Gymnodinium abbreviatum Kofoid \& Swezy (1921: 180), Gymnodinium achromaticum M.Lebour (1917: 190), Gymnodinium amphora Kofoid 
\& Swezy (1921: 185), Gymnodinium dogielii Kofoid \& Swezy (1921: 205), G. lohmannii Paulsen (1908: 99), (=Gymnodinium roseum Lohmann (1908: 263)), Gymnodinium situla Kofoid \& Swezy (1921: 257), Gyrodinium cuneatum Kofoid \& Swezy (1921: 297), (=Gymnodinium gracile sensu Pouchet 1885).

\section{Acknowledgements}

F.G. was supported by the convention \#2101893310 between CNRS INSU and the French Ministry of Ecology (MTES) for the implementation of the Monitoring Program of the European Marine Strategy Framework directive (MSFD) for pelagic habitats and the descriptor 'biodiversity'. Samples were collected during the ECOPEL Manche 2018 spring and summer cruises (CNRS-LOG) onboard R/V "Antea" (IRD, Institut de Recherche pour le Développement) in the frame of the cited convention and the CPER 'Hauts de France' project MARCO supported by the French state, the 'Hauts de France' French Region and the European Regional Development Founds (ERDF).

\section{REFERENCES}

Baytut, Ö., Gürkanli, C. T., Deniz, E., Özkoç, I. \& Gönülol, A. 2016. First molecular records of potentially harmful planktonic dinoflagellates from the southern Black Sea. Turk. J. Bot. 40:546-56.

Bergh, R. S. 1881. Der organismus der Cilioflagellaten. Eine phylogenetische studie. Morphol. Jahrb. 7:177-288.

Elbrächter, M. 1979. On the taxonomy of unarmored dinophytes (Dinophyta) from the Northwest African upwelling region. Meteor Forsch. Ergebnisse Reihe D 30:1-22.

Gómez, F. \& Boicenco, L. 2004. An annotated checklist of dinoflagellates in the Black Sea. Hydrobiologia 517:43-59.

Gómez, F., López-García, P., Takayama, H. \& Moreira, D. 2015. Balechina and the new genus Cucumeridinium gen. nov. (Dinophyceae), unarmored dinoflagellate with thick cell coverings. J. Phycol. 51:1088-105. 
Gómez, F., Artigas, L. F. \& Gast, R. J. 2019. Molecular phylogeny of the parasitic dinoflagellate Syltodinium listii (Gymnodiniales, Dinophyceae) and generic transfer of Syltodinium undulans comb. nov. (=Gyrodinium undulans). Eur. J. Protistol. 71:125636.

Hansen, G. \& Larsen, J. 1992. Dinoflagellater i danske farvande. In Thomsen H. A. [Ed.] Plankton i indre danske farvande. vol. 11, Miljøstyrelsen, Havforskning fra Miljøstyrelsen, vol. 11, pp. $45-155$.

Kofoid, C. A. \& Swezy, O. 1921. The free-living unarmored Dinoflagellata. Mem. Univ. Calif. $5: 1-562$.

Lebour, M. V. 1917. The Peridiniales of Plymouth Sound from the region beyond the Breakwater. J. Mar. Biol. Assoc. UK 11:183-200.

Pouchet, G. 1885. Contribution à l'histoire des Péridiniens marins. J. Anat. Physiol. Norm. Pathol. Homme Anim. 21:28-88. 
Fig. 1. Phylogenetic tree based on SSU rRNA gene sequences, showing the position of the sequences of Gymnodinium gracile by Maximum Likelihood (ML). Numbers near branches denote ML bootstrap probability value. Bootstrap values $<70$ are omitted. The inset shows the environmental sequences closer to the new sequences. The geographic origin is placed between parentheses. Scale bar denotes 0.02 substitutions per site.

Fig. S1. Map of the sampling stations during the ECOPEL-2 cruise.

Fig. S2. Light micrographs of live cells of Gymnodinium gracile from the English Channel in July 2018 .

Fig. S3. Phylogenetic tree based on LSU rRNA gene sequences.

Appendix S1. Historical account of Gymnodinium gracile and allied species names.

Appendix S2. Molecular methods. 
99 Levanderia fissa EF492497

Levanderina fissa KP790163

99. Akashiwo sanguinea KJ728857

Akashiwo sanguinea U41085

99 - . bipes AF231805

P. cinctum DQ166209

99 - C. coeruleum KR139785

Cucumeridinium lira

99

Gymnodinium gracile FG6 MW077542

Gymnodinium gracile FG3 MW077537

G. amphora KR139791(Brazil)

G. amphora KR139792 (Brazil)

G. amphora KR139790 (Brazil)

B. pachyderm. KR139789 (Spain)

SGUH701 KJ763266 (California)

Clone ds070.0 JQ956083 (Arctic)

cl 24 HM749926 (Black Sea)

GU825613 (Caribbean Sea)

Gymnodinium gracile FG4 MW077541

Balechina pachydermata KR139789

Gymnodinium amphora KR139792

97Lebouridinium glaucum KP790160

Lebouridinium glaucum KP790161

99-Torodinium teredo KR139783

Torodinium robustum KR139784

83 . Prorocentrum steidingerae EU28748

95 Prorocentrum mexicanum Y16232

GU824812 (Caribbean Sea)

G. gracile FG3 MW077537

G. gracile FG4 MW077541

- Clone KJ763198 (California)

- Clone KJ763422 (California)

GU825009 (Caribbean)

-DQ310213 (North Sea)

GU825090 (Caribbean)

EF526874 (North Sea)

76) $P$ seliodinium pirum MH469533

- Pseliodinium pirum MF948385

- Gertia stigmatica LC490696

Karenia papilionacea HM067005

1'- Brachidinium capitatum HM066998

Karenia brevis EF492502

Karenia mikimotoi MG022774

99

Shimiella gracilenta MN965778

Takayama cf. pulchellum AY800130

Takayama acrotrocha HM067010

81 Karlodinium jejuense MG365892

Karlodinium veneficum AY245692

93 Karlodinium veneficum EF492506

99. Ornithocercus magnificus EU780649

-Dinophysis caudata EU780644

- Syltodinium listii MK629451

95-Gymnodinium fuscum AF022194

Gyrodinium spirale AB120001

G_Gyrodinium jinhaense MH665394

Gyrodinium heterostriatum MT677910

93 Gyrodinium rubrum AB120003

-Margalefidinium polykrikoides JX967271

0.02

99 Margalefidinium polykrikoides AY421779

99 - Amph.operculatum EF057406

Syndinium turbo DQ146404

A. gibbosum AB863027

jpy_13135-20-233_f1.tif

This article is protected by copyright. All rights reserved 